\title{
PENGUATAN USAHA BATIK DI KUB BATIK FLAMBOYAN MELALUI DIVERSIFIKASI PRODUK BATIK BERBAHAN PEWARNA ALAMI SERTA DESAIN INSTALASI PENGOLAHAN LIMBAH
}

\author{
Mustagfirin $^{1 *}$, Yance Anas ${ }^{2}$, Darmanto ${ }^{3}$, Laeli Kurniasari ${ }^{4}$, Indah Hartati ${ }^{4}$ \\ ${ }^{1}$ Jurusan Teknik Informatika, Fakultas Teknik, Universitas Wahid Hasyim Semarang \\ Jl. Menoreh Tengah X No.22, Sampangan, Kec. Gajahmungkur, Kota Semarang, 50232 \\ ${ }^{2}$ Jurusan Farmasi, Fakultas Farmasi, Universitas Wahid Hasyim Semarang \\ Jl. Menoreh Tengah X No.22, Sampangan, Kec. Gajahmungkur, Kota Semarang, 50232 \\ ${ }^{3}$ Jurusan Teknik Mesin, Fakultas Teknik, Universitas Wahid Hasyim Semarang \\ Jl. Menoreh Tengah X No.22, Sampangan, Kec. Gajahmungkur, Kota Semarang, 50232 \\ ${ }^{4}$ Jurusan Teknik Kimia, Fakultas Teknik, Universitas Wahid Hasyim Semarang \\ Jl. Menoreh Tengah X No.22, Sampangan, Kec. Gajahmungkur, Kota Semarang, 50232 \\ *Email: mustagfirin@ unwahas.ac.id
}

\begin{abstract}
Abstrak
KUD Batik Flamboyan merupakan kelompok usaha pembuatan batik khas Grobogan yang berlokasi di Pulorejo Grobogan. Permasalahan utama yang dihadapi oleh KUB Flamboyan adalah KUB Flamboyan tidak memiliki instalasi pengolahan limbah serta batik diproduksi dengan pewarna sintesis. Tujuan kegiatan pengabdian ini adalah menerapkan instalasi pengolahan limbah dengan sistem penjerapan bertingkat serta memberikan pelatihan penggunaan pewarna alami pada produksi batik KUB Flamboyan. Hasil kegiatan menunjukkan jika KUB flamboyan berhasil memahami dan menerapkan penggunaan pewarna alami pada produksi batiknya serta dihasilkan desain instalasi pengolahan limbah menggunakan prinsip adsorpsi bertingkat.
\end{abstract}

Kata kunci: KUB Flamboyan, batik, Grobogan, pewarna alami, IPAL

\section{PENDAHULUAN}

Kabupaten Grobogan merupakan salah satu kabupaten di Jawa Tengah dengan letak astronomis di antara $110^{\circ} 15^{\prime} \mathrm{BT}-111^{\circ} 25^{\prime} \mathrm{BT}$ dan $7^{\circ} \mathrm{LS}-7^{\circ} 30^{\circ e} \mathrm{LS}$. Secara administrasi Kabupaten Grobogan terdiri dari 19 kecamatan dan 280 desa/kelurahan dengan ibukota berada di Purwodadi. Salah satu kecamatan yang ada di Kabupaten Grobogan adalah Kecamatan Purwodadi dimana salah satu desa yang ada kecamatan Purwodadi adalah desa Pulorejo. Salah satu usaha kecil menengah yang ada di Desa Pulorejo Kecamatan Purwodadi adalah usaha pembuatan batik tulis. Di desa Pulorejo terdapat setidaknya 4 buah Kelompok Usaha Bersama (KUB) yang bergerak dibidang pembuatan batik tulis Grobogan (Melati putih, Gatotkaca, Flamboyan, dan serang). KUB flamboyan yang diketuai oleh Ibu Nunung Wijayanti merupakan KUB berdiri sejak tahun 2010 serta memiliki anggota kelompok yang cukup banyak. KUB yang bergerap dibidang produksi batik tulis tersebut berdiri setelah mereka mendapat pelatihan dari Dinas Perindustrian dan Perdagangan Kabupaten Grobogan. Hal yang melatarbelakangi kegiatan pelatihan pembuatan batik tulis adalah adanya keinginan agar Kabupaten memiliki batik tulis yang menjadi kekhasan dari daerah Grobogan, seperti halnya batik-batik yang telah dimiliki dan menjadi ke khasan dari daerah daerah lain seperti batik Solo, pekalongan, batik Bakaran dari Lasem dan lain-lain.

KUB flamboyan telah berhasil bertahan dalam memproduksi batik khas Grobogan. Namun demikian, KUB flamboyan menghadapi permasalahan terkait pengolahan limbah serta masih kurangnya wawasan dan ketrampilan akan penggunaan pewarna alami pada proses pembuatan batik. Oleh karena itu, melalui kegiatan pengabdian kepada masyarakat, tim pengabdian telah melakukan 
kegiatan penguatan usaha produksi batik pada KUB Batik Flamboyan dengan memberikan pelatihan penggunaan pewarna alami serta penerapan desain IPAL dengan system penyerapan bertingkat.

\section{METODE}

Kegiatan dilaksanakan dengan tahapan sebagaimana tersaji pada Gambar 1.

Pelatihan mengenai pewarna alami: jenis, cara produksi pewarna, dan teknik penerapan pewarnaan batik
Praktik penerapan pewarna alami pada pembuatan batik
Batik Grobogan dengan pewarna alami

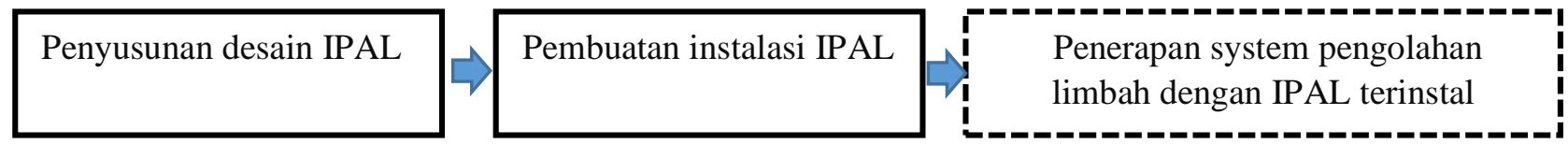

Gambar 1. Tahapan pelaksanaan kegiatan

\section{HASIL DAN PEMBAHASAN}

KUB Batik Flamboyan mengawali proses pembuatan batik dengan proses menggambar pada kain. Setelah kain selesai digambar, proses dilanjutkan dengan proses canting, proses pewarnaan, proses penguncian warna, proses pembilasan, proses pelorotan, proses pembilasan, pengangin-anginan dan proses penjemuran. Tahapan proses pembuatan batik di KUB flamboyant disajikan pada Gambar 2.

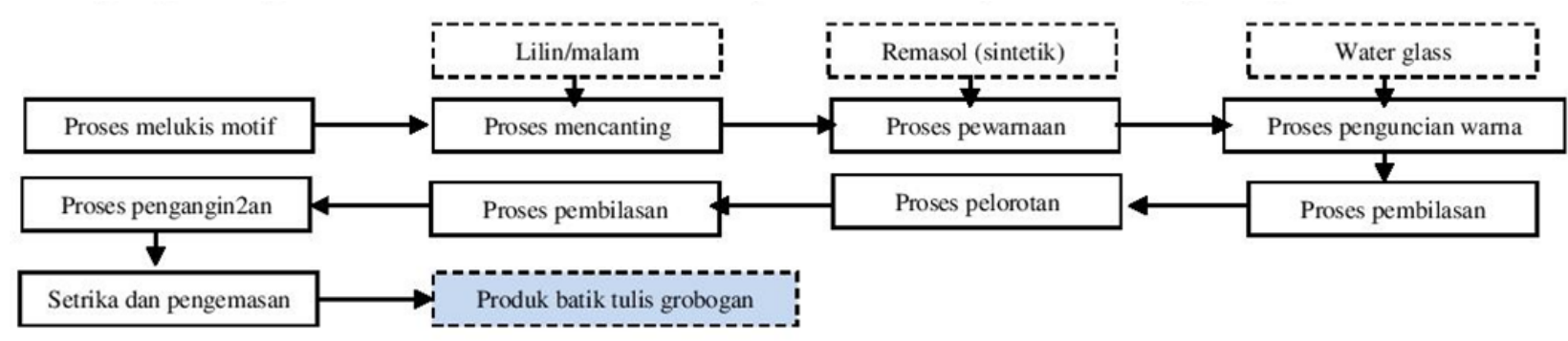

Gambar 2. Tahapan proses pembuatan batik oleh KUB Flamboyan
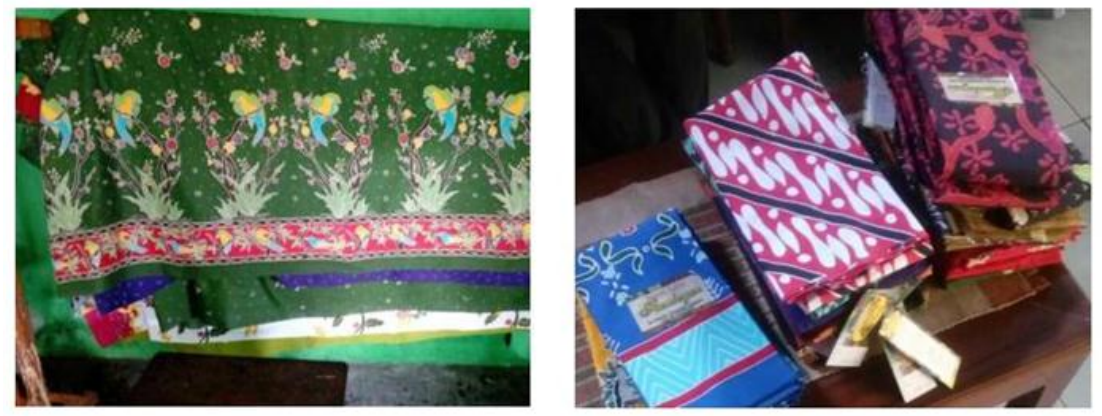

Gambar 3. Batik dengan pewarna sintesis produksi KUB Flamboyan

Selama ini batik (Gambar 3) yang dihasilkan oleh KUB Flamboyan memiliki ciri khas warna yang menyolok karena dihasilkan dari proses pewarnaan dengan pewarna sintesis. Menimbang bahwa sebagian besar produksi batik pada KUB batik yang ada Grobogan masih didominasi oleh produksi batik dengan pewarna sintesis, maka pelatihan mengenai pewarna alami memiliki peran penting dalam 
meningkatkan wawasan anggota KUB mengenai pewarna alami. Pelatihan mengenai pewarna alami yang telah dilaksanakan telah berhasil memberikan wawasan mengenai jenis-jenis tanaman serta bagian-bagian tanaman yang dapat digunakan sebagai pewarna alami pada produksi batik sebagaimana disajikan pada Tabel 1 .

Tabel 1. Jenis bahan penghasil pewarna alami

\begin{tabular}{clll}
\hline No & Nama Tanaman & Bagian Tanaman & Warna yang dihasilkan \\
\hline 1 & Nila & Daun & Biru \\
2 & Tingi & Kulit kayu & Coklat \\
3 & Asam belanda & Daun & Coklat, hijau \\
4 & Alpukat & Daun & Coklat, abu abu, coklat kehijauan \\
5 & Tegeran & Batang & Kuning \\
6 & Putri malu & BUnga, daun & Kuning kehijauan \\
7 & Nangka & Batang & Kuning \\
8 & Jati & Daun muda & Merah kehitaman \\
9 & Bawang merah & Kulit buah & Coklat \\
10 & Mahoni & Batang & Coklat \\
11 & Mengkudu & Kulit akar & Merah \\
12 & Secang & Batang & Merah \\
13 & Bunga sepatu & Sari tepung & Ungu \\
14 & Kenikir & Daun & Kuning \\
15 & Bougenville & Bunga & Merah coklat \\
16 & Kelapa & Serabut & Kuning merah \\
17 & Kunyit & Rimpang & Kuning, jingga \\
18 & Manga & Daun & Coklat, kuning, abu abu, \\
19 & Pisang & Pelepah & Coklat, abu abu \\
\hline
\end{tabular}

Setelah mendapatkan pelatihan anggota KUB Flamboyan memahami jika pada dasarnya ada berbagai ragam bahan baku yang dapat dengan mudah ditemukan di sekitar wilayah mereka yang dapat digunakan sebagai bahan baku pembuatan pewarna alami. Pada kegiatan pelatihan (Gambar 4) juga disampaikan jika pembuatan pewarna alami merupakan proses yang mudah. Ekstraksi pewarna alami dapat dilakukan dengan perebusan bahan bahan sumber pewarna alami menggunakan air.

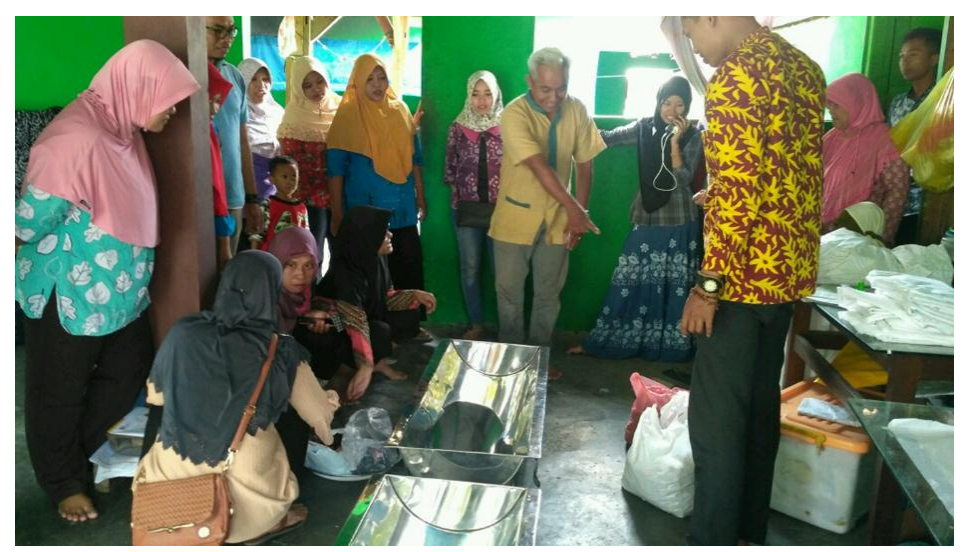

Gambar 4. Proses pelatihan bertema pewarna alami

Anggota KUB Flamboyan yang telah mendapatkan pelatihan mengenai pewarna alami mempraktekkan penggunaan pewarna alami pada produksi batik mereka. Batik yang dihasilkan disajikan pada Gambar 5. Gambar 5 memperlihatkan bahwa dengan menggunakan pewarna alami tetap dapat mendapatkan 
batik dengan warna berintensitas kuat, meskipun variasi dan kekuatan warnanya tidak sebanyak dan sekuat seperti pada batik yang dihasilkan dengan pewarna sintesis (Gambar 3).
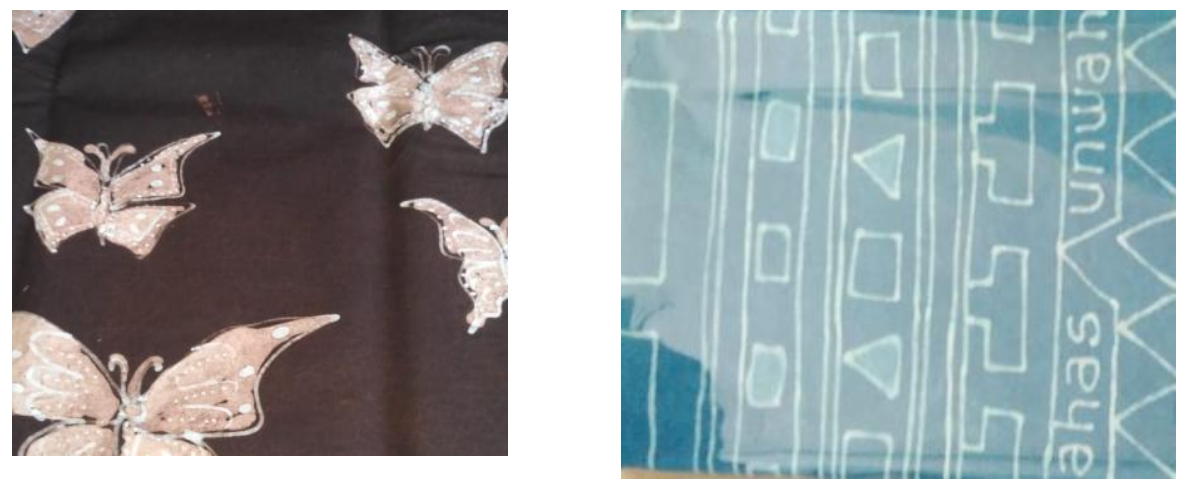

Gambar 5. Batik produksi KUB flamboyan yang dihasilkan dengan pewarna alami

Berdasarkan Gambar 5 bahwa KUB Flamboyan menerapkan pewarna alami pada batik yang digambar dengan motif non geometris dan motif geometris yang juga dihasilkan dari kegiatan pengabdian ini. Untuk patra non geometris yang dipilih untuk dibuat oleh KUB Flamboyan adalah obyek desain yang berasal dari unsur fauna (kupu-kupu). Indrojarwo (2017) menyatakan jika unsur desain dapat berasal dari flora, fauna, sosok manusia dan dongeng/legenda serta bentuk-bentuk geometris dasar. Selama ini motif khas batik Grobogan adalah motif motif yang terkait hasil pertanian. Motif unggulan dari batik Grobogan adalah "pajale" yang merupakan akronim dari padi, jagung dan kedelai. Pada tahun 2012 mereka sudah memiliki hak cipta motif yakni terong dan pring sedapur. Meskipun sudah memiliki motif unggulan namun mereka menyadari bahwa motif yang mereka miliki dan buat selama ini masih kurang bevariasi dan kurang "kaya" akan motif motif baru. Saat ini motif yang mereka buat lebih dominan pada motif non geometris. Oleh karenanya dengan pendampingan tim kegiatan pengabdian, bersamaan dengan penerapan hasil pelatihan mengenai pewarna alami, maka pewarna alami telah diterapkan pada pewarnaan batik yang digambar dengan motif geometris dan non geometris.
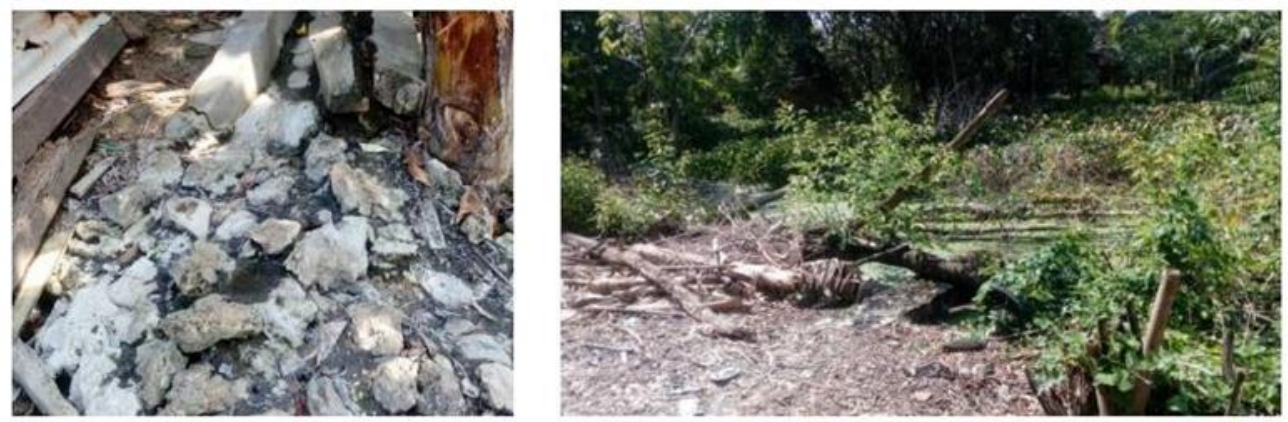

Gambar 7. Limbah batik dibuang kelingkungan tanpa diolah dan tanpa adanya IPAL

Kegiatan penguatan usaha KUB Flamboyan juga dilakukan melalui penerapan sistem pengolahan limbah batik mengingat proses pembuatan batik dengan pewarna sintesis menghasilkan limbah cair. Limbah dihasilkan setelah proses penguncian selesai dilakukan yang kemuduan dilanjutkan dengan proses pembilasan serta dilanjutkan proses pelorotan menggunakan pemasakan menggunakan drum untuk mengilangkan lilin yang menempel pada kain batik. Pada proses penguncian warna, proses pelorotan dan pembilasan tersebut, limbah cair dihasilkan. Selama ini mereka membuang limbah mereka ketanah tanpa melalui adanya proses pengolahan limbah (Gambar 6). Oleh karenanya 
kemudian sistem pengolahan limbah dikenalkan kepada KUB Flamboyan melalui desain IPAL yang disajikan pada Gambar 7.

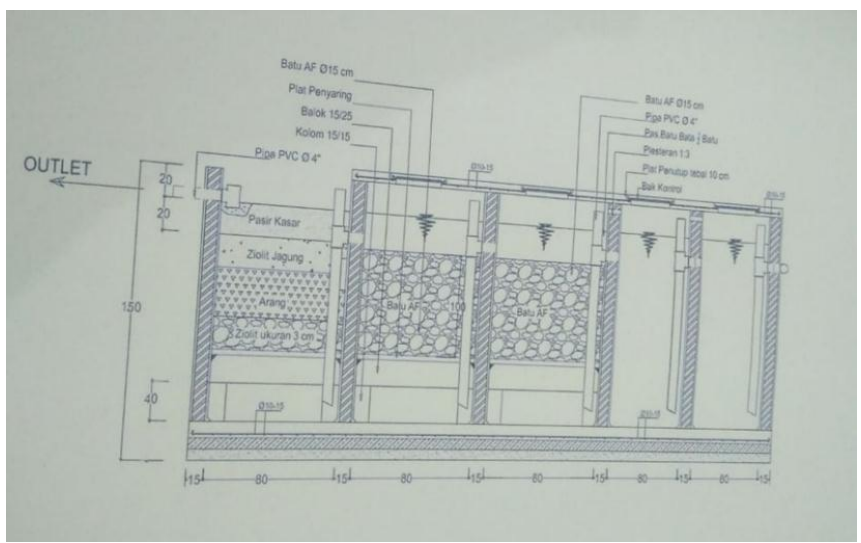

Gambar 7. Desain IPAL untuk KUB Flamboyan

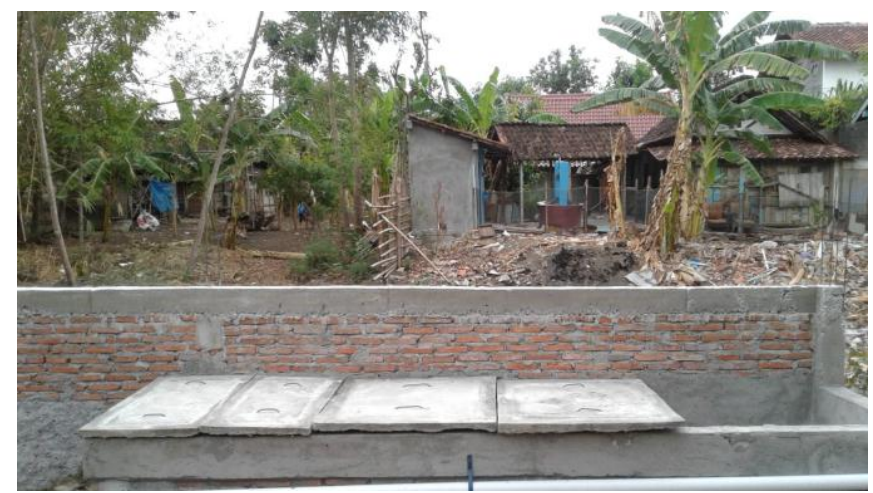

Gambar 8. Bentuk Jadi IPAL untuk KUB Flamboyan

IPAL yang diintroduksi pada KUB flamboyant berupa bak pengolahan limbah pengolahan batik yang terdiri atas 5 bagian atau chamber. Pada bagian awal (ruang 1), zat warna pada limbah batik akan diserap oleh material adsorben yang terdiri dari pasir, zeolite dan karbon aktif. Pada ruang 2 dan 3, bak diisi dengan batu apung. Diharapkan limbah batik yang diolah menggunakan IPAL ini akan mengghasilkan effluent yang masuk kriteria baku mutu air limbah.

\section{KESIMPULAN}

Kegiatan penguatan usaha pada KUB Flamboyan yang dilakukan melalui pelatihan pewarna alami telah berhasil meningkatkan wawasan dan ketrampilan anggota KUB mengenai jenis jenis bahan baku pewarna alami, cara ekstraksi pewarna alami dan penerapan pewarna alami pada batik bermotif geometris dan non geometris. Penerapan IPAL telah dilakukan oleh KUB Flamboyan dan menghasilkan eflluen limbah yang sesuai dengan baku mutu air limbah.

\section{DAFTAR PUSTAKA}

Indrojarwo B.T. 2017. Development of Indonesia New Batik Design by Exploration and Exploitation of New Context. Makalah pada Jurusan Desain Produk Industri. 